\title{
The Role of Agricultural Policies in Jordan to Mitigate the Effects of COVID-19 on the Agricultural Sector
}

\author{
Radi A. Tarawneh ${ }^{1}$ \\ ${ }^{1}$ Collage of Agriculture, Jerash University, Jerash, Jordan \\ Correspondence: Radi, A. Tarawneh, Collage of Agriculture, Jerash University, Jerash, Jordan. Tel: \\ 962-799-059-944. E-mail: m.tarawneh@jpu.edu.jo
}

Received: June 17, 2021

Accepted: July 31, $2021 \quad$ Online Published: August 15, 2021

doi:10.5539/jas.v13n9p171

URL: https://doi.org/10.5539/jas.v13n9p171

\begin{abstract}
Since early 2020, an outbreak of the coronavirus disease 2019 (COVID-19) has started to spread in Jordan challenging the sustainability of Jordan's economic sectors and the agricultural sector. A study was conducted in Jordan to evaluate the role of Jordanian Agricultural Policies to mitigate the effects of COVID-19 on the agricultural sector while its full impact on the Jordanian agricultural sector is not yet evident. A scientific questionnaire was distributed to 100 samples of Jordanians who had direct contact with the effect of agricultural policies and they can touch the effect of Coronavirus and Agricultural Policies on the agricultural sector, data selected from farmers, farm labour, fruits and vegetable traders and merchants, and Jordanian citizens were selected randomly from different areas in Jordan. The study summarizes target group opinion and some evidence on the different COVID-19 impacts on the Jordanian agricultural sector. The virus limits the free flow of labour, the agricultural labour force had a slightly decreased in 2020 compared with the year 2019 to about $7 \%$, the country lockdown led to damage of crops due to lack of harvest and/or crop accumulation, as a result, the Jordan Agricultural Contribution to GDP growth rate at current prices was decreased $1.4 \%$, and the growth rate at constant prices was also decreased $1.6 \%$, the exported agricultural commodities value were not affected by COVID-19 pandemic but the imported of Agricultural commodities value was increased. Jordanian government try to facilitate the process of agricultural production and the provision of food during the Corona pandemic through issue agricultural policies and measures to alleviate the effects of the Corona pandemic on the agricultural sector.
\end{abstract}

Keywords: Jordan Agricultural Policies, government measures, GDP, COVID-19, labour, markets

\section{Introduction}

Since the beginning of the year 2020, the world has suffered from the COVID-19 disaster, the world has taken remedial and preventive measures against the disease, because of the absence of the COVID-19 vaccine and understanding of the virus behavior, COVID-19-induced pandemic effects on the entire food system. It exerts asymmetric, asynchronous shock on global and national food systems. COVID-19 pandemic is continuing to spread around the world, causing hard times for many economies and sectors, including agriculture (Jámbor A., et al., 2020) the full impact of the virus on the agricultural sector in Jordan is not yet fully known, the agriculture sector is in the spotlight as food is necessary for us to live, and is also related to the Sustainable Development Goals. It's a fact that COVID-19 pandemic impacts turn out to be for food security, nutrition and the livelihoods of farmers, fishers, and others working along the food supply chain will depend in large part on policy responses, Jordan government manage multiple demands-responding to the health crisis, managing the consequences of the shock to the economy, and ensuring the smooth functioning of the food system. While the pandemic poses some serious challenges for the food system in Jordan, it is also an opportunity to accelerate transformations in the food and agriculture sector to build its resilience in the face of a range of challenges, Jordan government issue new strategies according to the challenges faces the Jordanian economic sectors, Jordan's strategy in facing the Corona pandemic was a set of measures based on the Defense Law that was approved since the beginning of the year2020 which is preventative measures and tips to reduce the spread of COVID-19 infection. This article aims to provide the current situation of the agricultural sector explaining the importance of agricultural policies in Jordan to confront the effects of the Corona pandemic through highlighted some government measures to confront the Corona pandemic and the effectiveness of these measures on the agricultural sector by surveying the 
opinions of those whom interested in the agricultural sector, namely farmers, fruits and vegetables merchants, Jordanian agricultural labour (farmworkers, trucks travelers) Jordanian agricultural engineers. The study will find answers of: Did COVID-19 affected the Jordanian agricultural sector? Did the governmental measures to counter the effects of the Corona pandemic on the agricultural sector was effective?

\section{Jordan Government COVID-19 Response}

COVID-19 pandemic and its socio-economic impact are evolving rapidly, with the impact of the crisis not only driven and shaped by the repercussions of the spread of the virus on the broader economy in Jordan but also the nature of the government response in terms of movement restrictions and other emergency measures and the support of Jordan's key development partners. Efforts to contain the spread of COVID-19 are essential to protect lives and avoid the collapse of health services (Kebde et al., 2020). Since the beginning of the COVID-19 pandemic, the Jordanian government has followed the recommendations and updates provided by the WHO. A series of preventive and control strategies at the local and national levels have been implemented to limit the spread of COVID-19 inside Jordan. COVID-19 was affected Jordanians, the number of infected persons increased dramatically during the period of March to April, 2020, data from Jordan Ministry of Health show that the confirmed new cases and cumulative cases of COVID-19 was increased from $15^{\text {th }}$ March to $16^{\text {th }}$ April, 2020, Figure 1.

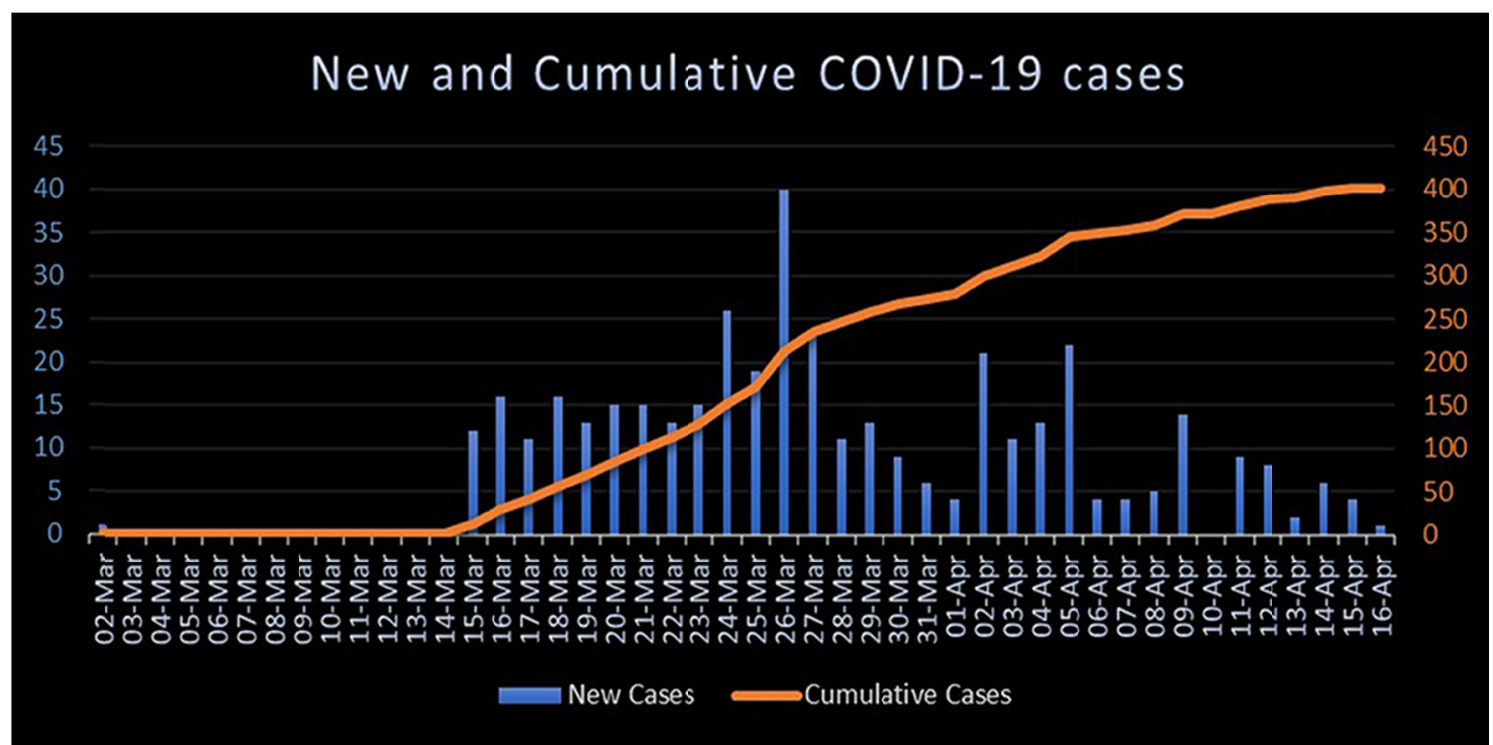

Figure 1. The number of new and cumulative cases of COVID-19 by date during the period between the 2 nd of March and the 16th of April 2020. Developed according to publicly declared statistics on the Jordanian COVID-19

Source: Jordanian Ministry of Health (2020).

Jordan Government responses started from the time when the World Health Organization announced the COVID-19 disaster, Jordan started to draw measures to protect the lives of Jordanians and avoid the collapse of health services. COVID-19 in Jordan is led by the government through a collaborative multi-disciplinary team at the highest levels at the National Center for Security and Crises Management (NCSCM), The decision-makers are experts from different ministries, sectors, and organizations to reach for and provide the best evidence-based recommendations for implementation (Jordan Prime Minister Cabinate, 2020; National Center for Security and Crises Management, 2020). Google mobility charts showed that individuals' mobility in Jordan has been effectively reduced during the curfew for places like grocery markets, food warehouses, farmer's markets, specialty food shops (Google Health, 2020).

In March 2020, the Government of Jordan close all borders and halt all travel, Jordanian return to Jordan allowed entry conditional to a self-imposed quarantine at home for 14 days and cancellation of all international and local conferences, additionally, the government, from March 10 to 17, 2020, closed of educational institutions and started with the Distance/Remote Learning Plan, prevent all public events, closed of mosques and churches, 
closed off all historic tourist sites, cinemas, swimming facilities, sports clubs, and youth centers and coffee shops and restaurants. The Ministries, government departments, public/official establishments remain open to provide services during the pandemic time. At that time, the government announced the implementation of the National Defence Law No. 13 of 1992 in the Kingdom, as of Wednesday 17, March 2020, as a result, the government lockdown Jordan, the Prime Minister Cabinet affirmed that the Jordanian citizens must not leave their houses except in the most urgent cases, restricting the importation or transfer of goods from one place to another and prohibiting their concealment, purchase of battering, and setting prices, on the other hand, the government allowed doorstep delivering of water, bread, and baby formula with a specific time for people to get their needs.

The Jordan Government was aware of the importance of the agricultural sector at the COVID-19 pandemic, the government offers an official movement license for the agricultural sector workers, farmers who owned the farm, farmworkers, trucks, and drivers for transporting of agricultural production from production units to wholesale markets and offer all services for farmers to continue their production process, without exporting of agricultural products abroad because of closing borders (Table 1).

Table 1. Jordan Governmental Measures against COVID-19 pandemic during the year 2020

\begin{tabular}{|c|c|c|}
\hline \multicolumn{2}{|l|}{ Date } & Jordan Government Measures against COVID-19 Pandemic \\
\hline \multirow{5}{*}{2020} & $1^{\text {st }}$ March & $\begin{array}{l}\text { Ministry of Health dedicated website for the COVID-19 pandemic in Jordan } \\
\text { Ministry of Health COVID-19 hotline: } 111 \\
\text { Portal for all government platforms related to dealing with COVID-19 }\end{array}$ \\
\hline & $6^{\text {th }}$ March & $\begin{array}{l}\text { The Jordanian government made an agreement with Facebook to launch an awareness campaign regarding COVID-19. } \\
\text { Facebook will present all site visitors from within the Kingdom with links to the Ministry of Health website promoting } \\
\text { its content intended to increase awareness of the outbreak, preventative measures and tips to reduce the spread, and the } \\
\text { dedicated facilities for testing and treatment }\end{array}$ \\
\hline & $10^{\text {th }}$ March & $\begin{array}{l}\text { The Governmental measures was: } \\
\text { - Halt on travel to/from Lebanon. } \\
\text { - Halt all travel to/from Syria except for trucks. } \\
\text { - Closing of Sheikh Hussein (Northern) crossing with Israel, King Hussein/Allenby Bridge with the West Bank, Wadi } \\
\text { Araba (Southern) crossing with Israel for all passengers except official delegations, cargo personnel and Jordanian } \\
\text { workers using the Wadi Araba crossing. } \\
\text { - Prevention of arrivals from France, Spain and Germany starting } 16 \text { March 2020, and prevention of Jordanians from } \\
\text { travelling to those countries. } \\
\text { - Closing of sea crossings with Egypt, and reducing planes incoming from Egypt by } 50 \% \text { and allowing only urgent } \\
\text { travel to Egypt while maintaining trade operations as normal. } \\
\text { - Halting passenger movement through Al-Karameh border crossing with Iraq, except for official delegations, while } \\
\text { maintaining commercial movement. Baghdad airport and Erbil airports are to be the only points of entry to/from Iraq } \\
\text { for passengers. Jordanians returning from all the above will be allowed entry conditional to a self-imposed quarantine } \\
\text { at home for } 14 \text { days. Exempt from the above are diplomatic missions/international organizations, foreign investors } \\
\text { residing in Jordan conditional to being subjected to the precautionary measures imposed by the Ministry of Health. } \\
\text { - Cancellation of all international and local conferences except those explicitly allowed by the cabinet. }\end{array}$ \\
\hline & $11^{\text {th }}$ March & $\begin{array}{l}\text { The Governmental measures was: } \\
\text { - Preventing non-Jordanians from entering the Kingdom from the following countries: China, South Korea, Iran, } \\
\text { Italy. Jordanians from the aforementioned will be quarantined on arrival. } \\
\text { - Banning vacations for expatriates working in Jordan. } \\
\text { - Halting new work permits for workers from abroad. } \\
\text { - Banning vacations for foreign students studying in Jordan wishing to travel to countries where the disease has } \\
\text { spread. } \\
\text { - Banning school trips to foreign countries. } \\
\text { - Suspending of public servants travel to foreign countries except for in extremely urgent cases and only when } \\
\text { approved by the cabinet. } \\
\text { - Suspending all tourist travel between Jordan and Palestine/Israel. } \\
\text { - Advising citizens against travel except in extremely urgent cases. } \\
\text { - Directing citizens arriving from countries with large numbers of COVID-19 cases (such as Iraq, Egypt, France, } \\
\text { Spain, Germany) to self-quarantine at home for two weeks and alerting health authorities in case of any } \\
\text { signs/symptoms of infection. }\end{array}$ \\
\hline & $14^{\text {th }}$ March & $\begin{array}{l}\text { The Governmental measures was: } \\
\text { - Prime Minister Omar Razzaz announced the following measures and directives that the government has undertaken } \\
\text { to deal with the COVID-19 virus and in light of the accelerating international developments: } \\
\text { - Educational Sector: } \\
\text { (1) Halting all educational institutions operations starting the morning of March } 15 \text { for the duration of two weeks. } \\
\text { (2) Ministry of Education to coordinate administrative staff work/shifts. }\end{array}$ \\
\hline
\end{tabular}




\begin{tabular}{|c|c|}
\hline & 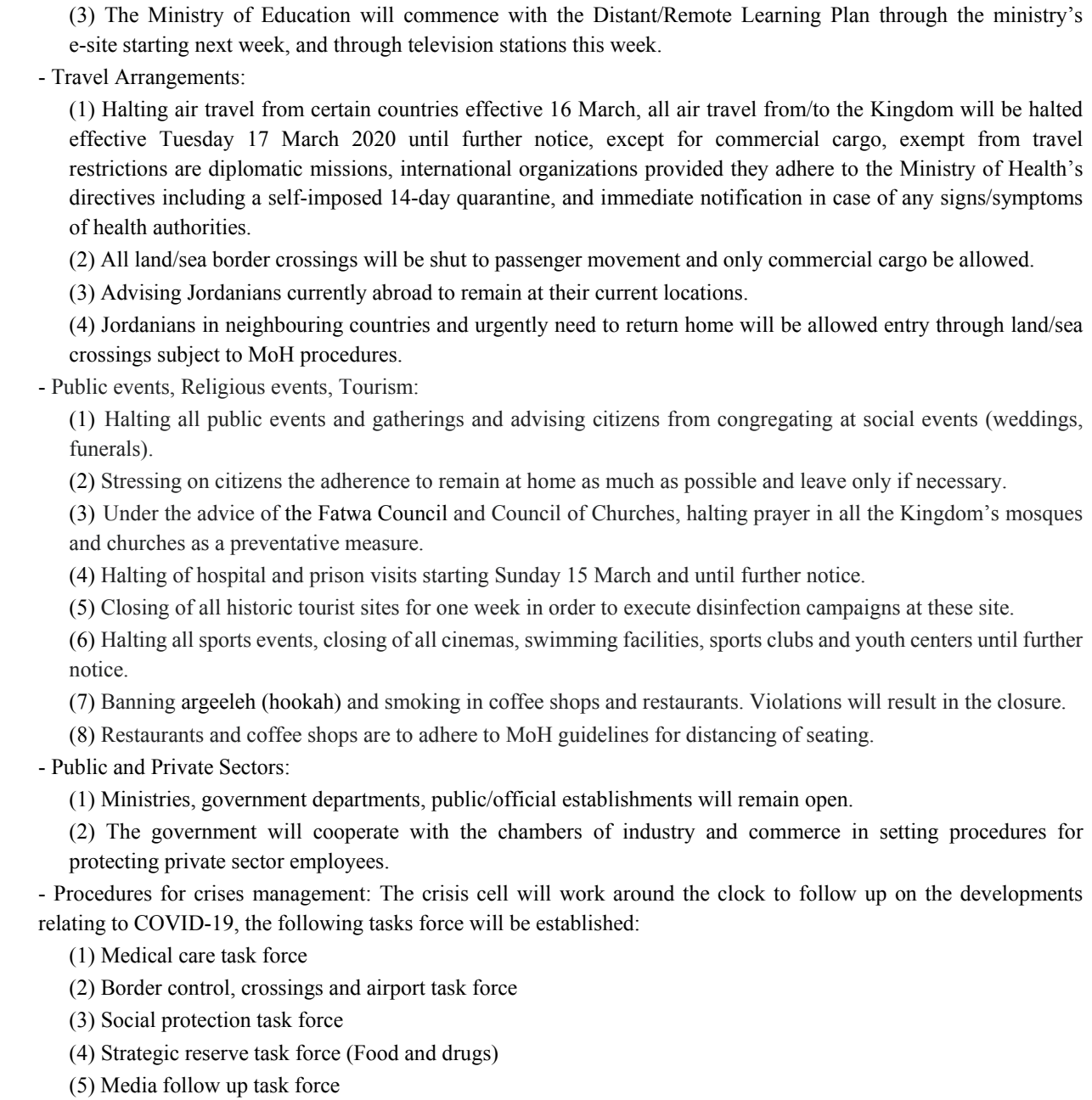 \\
\hline $17^{\text {th }}$ March & 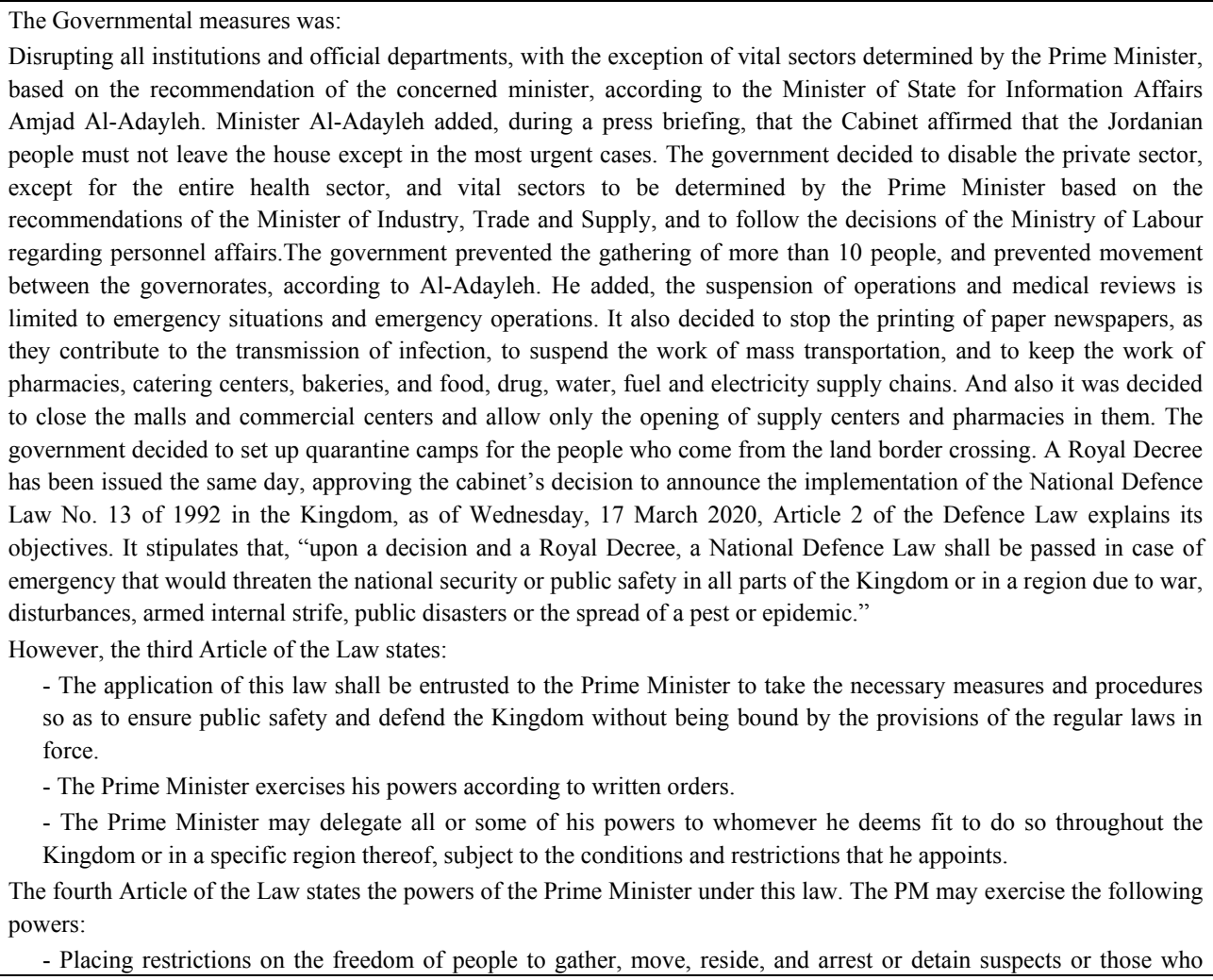 \\
\hline
\end{tabular}




\begin{tabular}{|c|c|}
\hline & $\begin{array}{l}\text { pose a threat to the national security and public order. } \\
\text { - Assigning any person to perform any work or service within their ability. } \\
\text { - Checking persons, places, and vehicles without being bound by the provisions of any other law, and ordering the } \\
\text { use of appropriate force in the event of opposition. } \\
\text { - Setting possession of movable and immovable property and postponing debt payment and the accrued liability. } \\
\text { - Preventing or restricting the importation, exportation or transfer of goods from one place to another and prohibiting } \\
\text { their concealment, destruction, purchase or bartering them, and setting their prices. } \\
\text { - Seizing any land, building, road, or source of water and energy, removing any trees or installations on them, } \\
\text { establishing facilities for defence purposes instead and ordering the concerned parties to manage, exploit and } \\
\text { organize their use. } \\
\text { - Evacuating or isolating some areas and imposing curfew on them. } \\
\text { - Ordering some or all public stores to open and close at specific times. } \\
\text { - Regulating and specifying transportation between different regions, blocking any road or water stream or changing } \\
\text { its direction and preventing traffic or regulating it. } \\
\text { - Monitoring messages, newspapers, publications, pamphlets, drawings, and all means of expression, publicity and } \\
\text { advertisement before they are published and seizing, confiscating, suspending, and closing the places where they } \\
\text { were prepared. } \\
\text { - Preventing taking pictures or making designs or maps for any specific place or thing that might benefit the enemy, } \\
\text { preventing having any photographic equipment or materials for making photos, designs and maps in such places and } \\
\text { preventing staying for so long in those places without a legitimate excuse. } \\
\text { - Cancelling licenses of firearms, ammunition, explosives, or explosive materials that are used in the manufacture of } \\
\text { explosives, preventing their manufacture, sale, purchase, transfer, disposing them, ordering their delivery and seizure, } \\
\text { and closing the shops where they are sold or stored. } \\
\text { - Preventing the manufacture, sale, purchase or possession of telecommunications equipment and ordering their } \\
\text { delivery and seizure. }\end{array}$ \\
\hline $18^{\text {th }}$ March & $\begin{array}{l}\text { The Ministry of Tourism and Antiquities dedicates a round-the-clock toll free hotline number } 91040 \text { for enquirers and } \\
\text { complaints of those under quarantine. }\end{array}$ \\
\hline $20^{\text {th }}$ March & $\begin{array}{l}\text { The Governmental measures was: } \\
\text { The government has decided to impose a curfew in Jordan, as part of its measures to fight coronavirus. Citizens will be } \\
\text { officially banned from moving in all regions of the Kingdom, from 7:00 am tomorrow, until further notice. As he } \\
\text { announced Defence Order No.2 during a press briefing today, Minister of State for Media Affairs Amjad Adaileh pointed } \\
\text { out that all the stores in all regions of the Kingdom will be closed. }\end{array}$ \\
\hline $22^{\text {nd }}$ March & $\begin{array}{l}\text { The Governmental measures was: } \\
\text { - The government allowed Gas and Water deliveries. } \\
\text { - Minister of Digital Commerce and Entrepreneurship Mothanna Gharaibeh announces distant learning platform. 70, } \\
000 \text { students have started using this platform since this morning. The platform was developed in less than a week, to } \\
\text { allow students to study from home. Telecommunication companies agreed to provide free access to the platform daily } \\
\text { from 6:00 am to 4:00 pm, the government, in turn, allowed access to an expanded range of frequencies to allow for } \\
\text { the expansion of the services and provide additional needed bandwidth. } \\
\text { - Minister of Education Dr. Tayseer Al No'aimi announces the launch of the e-learning platform starting 7:00 this } \\
\text { morning till 16:00 for grades-12. The launch of the platform in response to His Majesty's directives and the prime } \\
\text { minister's continued follow-up to ensure the right to education for all students. The e-learning platform supplements } \\
\text { the newly launched TV stations "Jo Darsak 1" and "Jo Darsak 2" designated for students of all grades. }\end{array}$ \\
\hline 23 March & $\begin{array}{l}\text { The Governmental measures was: } \\
\text { The government allowed doorstep deliveries of water, bread, and baby formula. } \\
\text { However, the government will announce on Tuesday, } 24 \text { March, specific times for people to get their needs within a } \\
\text { mechanism that will be announced at that time. } \\
\text { "Anyone who violates the provisions of this Order and the measures issued by the Prime Minister and the Minister of } \\
\text { Defence shall be liable to immediate imprisonment for a period not exceeding one year," Adaileh confirmed. As for } \\
\text { emergency medical cases, citizens must inform the Public Security Directorate (PSD) or the Civil Defence Directorate } \\
\text { (CDD) to take the necessary measures to protect their health and safety according to the rules. People authorized by the } \\
\text { Prime Minister and the Minister of Defence, based on their work nature, are excluded from the decision. }\end{array}$ \\
\hline $24^{\text {th }}$ March & $\begin{array}{l}\text { The Governmental measures was: } \\
\text { Prime Minister Omar Razzaz announced that small neighbourhood grocery and convenience stores along with } \\
\text { pharmacies, drinking-water stores and bakeries, will be allowed to open from 10:00 to 18:00 starting Wednesday } 25 \text { of } \\
\text { March. Citizens between the ages of } 16-60 \text { will be allowed to visit their neighbourhood stores on foot only to get basic } \\
\text { supplies; vehicles are still not permitted. Persons are to travel individually and maintain a distance of no less than } 1.5 \\
\text { meters between one another at all times. Larger supermarkets are planned to be allowed to sell and deliver items to } \\
\text { citizen's homes starting Thursday } 26 \text { March. This comes after the partially successful attempt to distribute bread to } \\
\text { citizens directly to prevent them leaving their homes. }\end{array}$ \\
\hline $25^{\text {th }}$ March & $\begin{array}{l}\text { The Ministry of Health receives } 21,000 \text { additional test kits and expands testing efforts. The MoH reaffirms that it is } \\
\text { ready to test any suspected cases and urges citizens to contact the hotline } 111 \text { for all queries regarding "Corona". }\end{array}$ \\
\hline $26^{\text {th }}$ March & $\begin{array}{l}\text { The Governmental measures was: } \\
\text { The Prime Minister announces Defence Order \#3 for the year 2020: }\end{array}$ \\
\hline
\end{tabular}




\begin{tabular}{|c|c|}
\hline & $\begin{array}{l}\text { Disobeying Order \#2 of Defence Law for } 2020 \text { will result in the following punishments: } \\
\text { - A fine between } 100 \text { and } 500 \text { JDs for the first offence. } \\
\text { - Imprisonment for no more than one year and/or a fine of } 100-500 \text { JDs for the second offence } \\
\text { - Any vehicle used without a permit will be impounded for } 30 \text { days. } \\
\text { - Any permitted store that opens outside of designated times will be fined no less than } 1000 \text { JDs or the closure of the } \\
\text { store for } 14 \text { days. } \\
\text { - Any store that opens without permission to open will be closed for } 3 \text { months and/or fined } 3000 \text { JDs. }\end{array}$ \\
\hline 30 March & $\begin{array}{l}\text { The Governmental measures was: } \\
\text { The government started releasing Jordanians held in 14-day mandatory quarantine (inbound travelers). All individuals } \\
\text { will sign/commit to self-quarantine for the next } 14 \text { days. The government will undertake the transport of all individuals } \\
\text { without cost to minimize interaction, mixing and exposure in route to their residences. } 3337 \text { persons of a total of } 3679 \\
\text { were released. } 2026 \text { were held in hotels in Amman, } 1311 \text { in the Dead Sea region, and } 16 \text { in Aqaba. }\end{array}$ \\
\hline $31^{\text {st }}$ March & $\begin{array}{l}\text { The Governmental measures was: } \\
\text { The government started releasing non-Jordanians held in 14-day mandatory quarantine back to their residences. } 1148 \\
\text { persons of } 67 \text { nationalities will be returned home after signing a commitment to another } 14 \text { days of self-isolation at } \\
\text { home. The government will also undertake the transport of these individuals as with Jordanians without cost to minimize } \\
\text { interaction, mixing and exposure in route to their residences. The government also announced Defence Order \#4 for the } \\
\text { year } 2020 \text {. }\end{array}$ \\
\hline $6^{\text {th }}$ April & $\begin{array}{l}\text { The government launched a website for citizens to request permits to leave their homes for urgent matters at movement } \\
\text { license currently the reasons permitted are: } \\
\text { - Going to the bank for company payroll purposes } \\
\text { - Going to the hospital } \\
\text { - Death cases }\end{array}$ \\
\hline $19^{\text {th }}$ April & All restaurants were re-opened in Aqaba. \\
\hline $3^{\text {rd }}$ May & $\begin{array}{l}\text { The prime minister issued Defence Order \#11 pertaining to the use of protective equipment by people. In summary } \\
\text { individuals in public places will be expected to wear a protective mask and gloves, failure to do so will result in a fine of } \\
\text { between } 20 \text { and } 50 \text { Jordanian Dinars. Those who work at facilities that serve the public (whether government or private), } \\
\text { will also have to adhere to wearing safety equipment and are subjected to heftier fines ranging from } 100 \text { to } 200 \text { Jordanian } \\
\text { Dinars per infraction along with the closing of the facility for } 14 \text { days. }\end{array}$ \\
\hline $5^{\text {th }}$ May & $\begin{array}{l}\text { Phase 1: Jordanian students being evacuated back home will start and commence until } 8 \text { May. } 3239 \text { students are expected } \\
\text { to be returned home and placed in quarantine. }\end{array}$ \\
\hline
\end{tabular}

Source: Wikipedia (2021).

\section{Jordan Government COVID-19 Agricultural Measures}

During the period of the Corona pandemic, the Jordanian government was keen with the agricultural sector to overcome the sector challenges in response to the royal vision which considers the agricultural sector as one of the most important national economy pillars that improve Jordan food security. Jordan government was aware on agricultural sector during the Corona pandemic, several agricultural policies were applied to reduce the effect of corona pandemic on agricultural sector; the Jordanian government has set price ceilings for some agricultural products, stop and postponing the agricultural loans payment for farmer's borrowers from the Agricultural Credit Corporation until the end of 2021, Jordan Trade Ministry sets wholesale price ceiling for in-demand vegetables, eggs, decision comes after ministry shuts down shops over unfair pricing (FAO, 2020), also, the government established incentives to increase the percentage of Jordanian employment through the government's contribution to social security coverage for Jordanian workers in the agricultural sector, reducing fees for foreign workers in the agricultural sector by $50 \%$, reducing the sales tax rate on all sales items and the remnants of prepared animal food and feed concentrates excluding cat food, birds, dogs and pigs from $5 \%$ to $0 \%$, reducing the tax rate on mineral or chemical fertilizers containing 2 or 3 fertilizers elements, namely nitrogen, phosphorus or potassium, and all types of fertilizers to $0 \%$, reducing the tax on agricultural production inputs to $0 \%$ instead of 5-16\% includes fertilizers and agricultural pesticides, feed and their inputs and agricultural equipment for the plant and animal sectors, increase the advance granted to the Agricultural Credit Corporation from the Central Bank to ensure that the institution continues to provide banking services to the agricultural sector, and exempt farmers, seed production companies and exported agricultural plant and animal consignments from laboratory examination fees to the end of 2021, reducing selling fees in central markets by $50 \%$, reducing the sales commission fees in the wholesale markets, which reach $6 \%$ of the sale value, activating the package to support exports by air in coordination with the national carrier through government tax exemptions for the carrier, on the other hand, Ministry of Labour, 2020 complies with a set of measures to help the agricultural sector overcome challenges in corporation with the Partnership Council for the Agricultural Sector in the Ministry of Labor, although, the government provided movement license during the quarantine period to all agricultural sector workers and the manufacturing industries labour which dependent on the agricultural sector and allowing the 
vegetables and fruits trucks to move during the lockdown period from 5:00 am until 12:00 pm, implement of "BACK TO BACK" system to unload truckloads at the border from foreign refrigerated trucks to Jordanian refrigerated trucks without entering Jordan (Prime Minister Cabinate, 2021).

\section{The Effect of COVID-19 on Jordan Agricultural Sector}

The corona pandemic shocks affect all the sectors of an economy, the pandemic disrupts demand and supply of food impacting the global supply chain (Mishra et al., 2021). These impacts have been widely felt, including the agricultural sector in Jordan. The lockdown and measures taken all over the world and Jordan in response to the coronavirus (COVID-19) outbreak continue to have profound consequences for businesses. But it's not always entirely clear how great the impact is or will be on the Jordanian agricultural sector and other economic sectors. The initial effects of the lockdown became evident in early March among various agricultural production and marketing systems.

COVID-19 was affected the Jordanian Agricultural sector at the beginning of the pandemic by the perishability of the products, a farmer is on strict planting and harvesting schedule and cannot modify production at will. Many farmers face such problems as additional days of storage make their products worthless. Springtime is acritical planting and harvesting time for many farmers in Jordan, and the pandemic has made agricultural markets even more unpredictable, it could summarize the impact of COVID-19 on the agricultural sector as follow:

\subsection{COVID-19 Impacts on Agricultural Labour}

Jordan's agricultural sector suffered during the pandemic period in many ways, the virus limits the free flow of labour. Farmers are also worried that they will not be able to hire enough workers, particularly for planting and harvesting. Travel restrictions make it especially hard for farmers, wholesalers, and retailers to sell their products, many of which are coming from abroad. Supermarkets which have generally became accustomed to just-in-time deliveries, are now faced with increased demand and panic buying (Cariappa et al., 2010) most of farmers and farm workers in Jordan have been suddenly restricted due to quarantine measures specially at the beginning of the pandemic during March, 2020, and there was loss of farm workers from COVID-19 deaths and serious illness, on the other hand, Agricultural labour fear of being infected by the virus, but at the same time fear of losing their jobs and salaries, the other agricultural sector labour such as critical employees along the supply chain like truck drivers storage workers, wholesale markets workers, fruit and vegetables packaging centers workers, fruit and vegetables traders and merchants can get sick, quarantined or forced to stay at home, enlarging the initial impacts (Mishra et al., 2021) as a result; the virus must causes a scarcity of agricultural labour force in Jordan, but the data from Jordan Department of Statistics, 2021, Table 2 shows that, the agricultural labour force did not highly decrease according to expectations, agricultural labour force was slight decreased at 2020 comparing with the year 2019 about 1658 agricultural workers (7\% decreased) and decreased about 2463 agricultural workers (10\% decrease) comparing with the year 2018, according to the Jordan ministry of health, Jordan recorded deaths causes by COVID-19, which expected to decrease the labour force due to death or fear of virus infection, Figures 1 show the number of new and cumulative cases of COVID-19 by date during the period between the $2^{\text {nd }}$ of March and the $16^{\text {th }}$ of April 2020. It is expected that the reasons for the slight decrease in the number of agricultural labourers in Jordan are due to the good planning from the government and the excellent government measures to protect public health from the virus which provide support policies for the agricultural sector in movement, transportation, and the trade of vegetables and fruits.

Table 2. Jordanian Agricultural Labour (more than 15 years' old who can work) during the years 2018 to 2020

\begin{tabular}{llll}
\hline Agricultural Labour & 2018 & 2019 & 2020 \\
\hline Male & 22,361 & 22,121 & 20,318 \\
Female & 2,343 & 1,777 & 1,923 \\
Total of Agricultural Labour & 24,704 & 23,899 & 22,241 \\
Total Jordan Labour & $1,411,265$ & $1,377,905$ & $1,338,308$ \\
\hline
\end{tabular}

Source: Jordan Department of Statistics, 2021

\subsection{COVID-19 Impacts on Agricultural Trade and Marketing}

It is common in times of global crisis; some countries have started to close their borders in the fear of decreased domestic supplies. Jordan was one of the countries that closed its borders with neighbouring countries such as 
Syria, Saudi Arabia, Iraq and cessation of air traffic from and to Jordan, which affect the food availability, it's expected that; the virus crisis could have a great impact on Jordan agricultural commodities trade, the data of agricultural commodities trade indicated that; the exported agricultural commodities was not affected by COVID-19 pandemic, the exported commodities value was increased 39.766 Million JD in the year 2020 compared with the year 2018 (from 720.678 Million JD in 2018 to 760.444 Million JD in 2020) with 5.5\% increase (Table 3).

Table 3. Jordan Agricultural Export during the years 2018 to 2020 (Value/Million JD, Quantity/Tones)

\begin{tabular}{|c|c|c|c|c|c|c|}
\hline \multirow{2}{*}{ Commodity } & \multicolumn{2}{|c|}{2018} & \multicolumn{2}{|c|}{2019} & \multicolumn{2}{|c|}{2020} \\
\hline & Quantity & Value & Quantity & Value & Quantity & Value \\
\hline Live animals and animal products & 144,155 & 133.294 & 138,315 & 174.072 & 687,497 & 175.474 \\
\hline Plant products & 563,168 & 343.053 & 579,592 & 300.052 & 473,098 & 288.914 \\
\hline Elements Produced from animal or plant & 1,291 & 2.840 & 1.688 & 2.629 & 5,041 & 6.188 \\
\hline Food industry products & 172,705 & 241.491 & 241.692 & 260.937 & 237,663 & 289.868 \\
\hline Total & 881,319 & 720.678 & 718,150 & 737.69 & $1,403,299$ & 760.444 \\
\hline
\end{tabular}

Source: Jordan Department of Statistics (2021).

Moreover, Table 4 shows that; the imported Agricultural commodities value was increased 168.994 Million JD in the year 2020 comparing with the year 2018 (from 720.678 Million JD in 2018 to 760.444 Million JD in 2020) with a $6.1 \%$ increase (DOS, 2021), the increase in imported and exported values could explain that; Panic shopping and stockpiling, the fear of being locked down for a longer period, people have started to buy up huge stocks of durable food in a relatively short period, which also causing difficulties for sale markets which was also explained by Jámbor et al. (2020).

Table 4. Jordan Agricultural imports during the years 2018 to 2020 (Value/Million JD, Quantity/Tones)

\begin{tabular}{|c|c|c|c|c|c|c|}
\hline \multirow{2}{*}{ Commodity } & \multicolumn{2}{|c|}{2018} & \multicolumn{2}{|c|}{2019} & \multicolumn{2}{|c|}{2020} \\
\hline & Quantity & Value & Quantity & Value & Quantity & Value \\
\hline Live animals and animal products & 229,279 & 601.063 & 237,956 & 619.874 & 176,828 & 681.249 \\
\hline Plant products & $3,537.929$ & $1,098.215$ & $3,256,698$ & $1,084.499$ & $3,189.924$ & $1,079.988$ \\
\hline Elements Produced from animal or plant & $174,697.312$ & 125.904 & 172.898 & 115.129 & 175,481 & 126.220 \\
\hline Food industry products & $1,104.139$ & 936.851 & $1,254,575$ & 912.962 & $1,405,958$ & $1,043.570$ \\
\hline Total & 408,618 & 2762.033 & $4,749,402$ & 2732.464 & $1,761,457$ & 2931.027 \\
\hline
\end{tabular}

Source: Jordan Department of Statistics (2021).

Lower economic growth and increasing trade restrictions have resulted in a continued and significant decline in the growth of global trade. The outbreak of COVID-19 early in 2020, and in particular the measures to contain the spreading of the disease are having significant consequences for economies. In response to the pandemic, governments around the world have implemented significant restrictions on personal and economic activities, resulting in shutdowns of parts of the economies (OECD, 2020). OECD (2020) estimates that the initial direct impact of the lockdowns could be a decline in the level of output of between one-fifth and one-quarter in many economies, with consumers' expenditures dropping by around one-third.

WTO (2020) reported that; the impact on annual Gross Domestic Product values (GDP) growth depends on a variety of factors, such as the magnitude and duration of national shutdowns, and the speed at which the significant fiscal and monetary policies take effect. Annual GDP could decline by up to 2 percentage points for each month that strict containment measures continue. International trade is likely to be hit even more strongly. The World Trade Organization (WTO) (2020) estimates that; world merchandise trade might shrink in 2020 by between 13\% and 32\% compared to 2019, Mishra et al. (2021) indicated that; the recent quarterly GDP estimates post-COVID scenario showcase robustness and resilience in Indian agriculture, the only sector to register positive growth of 3.4\% during the financial year (FY hereafter) 2020-21 (Quarter 1: April 2020 to June 2020), the Indian agriculture sector registered positive growth post-pandemic (3.4\% FY 2020-21 Quarter 1: April to June) but less than its immediate past quarter growth (5.9\% FY 2019-20 Quarter 4: January to March) witnessing a decline by $2.5 \%$ point due to the impact of COVID-19. In Jordan case, according to the Table 5, results 
indicated that; the contribution of the Jordanian Agricultural Sector to the Gross Domestic Product values (GDP) at current prices was increased 139 Million JD (1, 475 Million JD during 2018 to 1, 614 Million JD during the year 2020), the growth rate at current prices was decreased $1.4 \%$ (5.4\% during the year 2018 to $4 \%$ during the year 2020), and the contribution of the Jordanian Agricultural Sector to the Gross Domestic Product values at constant prices was increased 58 Million JD (1,380 Million JD during 2018 to 1, 438 Million JD during the year 2020), the growth rate at constant prices was decreased 1.6\% (3.2 \% during the year 2018 to $1.6 \%$ during the year 2020), these results could be explained that the contribution of the other Jordanian economic sectors to the Gross Domestic Product was increased, so that the Jordan Agricultural Contribution to GDP Growth rate was decreased.

Table 5. The contribution of the Jordanian Agricultural Sector to the Gross Domestic Product (Million JD) during the years 2018 to 2020

\begin{tabular}{llll}
\hline Jordan Agricultural Contribution to GDP at & 2018 & 2019 & 2020 \\
\hline Current Prices (Million JD) & 1,475 & 1,552 & 1,614 \\
Current Prices Growth \% & 5.4 & 5.2 & 4.0 \\
Constant Prices (Million JD) & 1,380 & 1,415 & 1,438 \\
Constant Prices Growth \% & 3.2 & 2.6 & 1.6 \\
\hline
\end{tabular}

Source: Jordan Department of Statistics (2021).

\section{Study Methodology}

According to the facts mentioned above, the agricultural sector was affected by COVID-19 government measures; this study will discuss and explain the effect of COVID-19 on the agricultural sector in Jordan and the effectiveness of agricultural policies to mitigate the effects of COVID-19 on the agricultural sector in different cases. A scientific questionnaire was distributed to 100 samples of Jordanians who had direct contact with the effect of agricultural policies and they can touch the effect of Coronavirus governmental measures and Agricultural Policies on the agricultural sector, data were selected randomly from different areas in Jordan. The study summarizes target group opinion and some evidence on the different COVID-19 impacts on the Jordanian agricultural sector. A study was conducted using of Triple Likert Scale Questionnaire, targeted farmers, farm labour, fruits, and vegetables traders and merchants, and Jordanian citizens, the questionnaire was distributed to 100 samples to study the effect of COVID-19 governmental measures at the agricultural sector and how agricultural policies mitigate the effects of COVID-19 on the Jordanian agricultural sector dealing with the effect of government measures on the agricultural labour, agricultural work, local and international markets, and agricultural production and production process in Jordan. Representative results from the questionnaire are reported. A completely randomized design (CRD) was used in this study and calculating the means. Analysis of variance (ANOVA) was performed using the SPSS Systems Computer package, Treatment means were compared by the least significant difference test at $\mathrm{P}=0.05$.

\section{Results and Discussion}

It is evident that the global pandemic has affected agriculture in many ways, since late 2019, an outbreak of the coronavirus disease 2019 (COVID-19) has rapidly spread all over the world, challenging the sustainability of economic sectors, one is the agricultural sector. The study tries to evaluate the agricultural policies to mitigate the effects of COVID-19 on the agricultural sector and the effect of governmental measures on the agricultural sector in Jordan, focusing on its effect on agricultural production and marketing system, study results depended on the questionnaire analysis, direct meeting, and notes of the targeted group.

6.1 The Impact of Agricultural Policies and Governmental Measures on Agricultural Sector During the Corona Pandemic According to Target Group Opinion

Table 6 shows that, the agricultural work was stopped due to fear from COVID-19 infection and the government measures during country lockdown which resulted in reducing the numbers of agricultural labour (it was agreed from 96 of targeted persons) and weaken financial capacity of agricultural entrepreneurs, also the Corona pandemic affected agricultural production flow to markets due to country lockdown and the closure of the borders(it was agreed from 84 of targeted persons) led to damage of agricultural crops due to lack of harvest or crop accumulation in field. Jordanians was believing that, the government agricultural measures were effective which facilitated the process of agricultural production and the provision of food and alleviated the effects of the Corona pandemic on the Jordanian agricultural sector (it was agreed from 72 of targeted persons). 
Table 6. Questionnaire element

\begin{tabular}{|c|c|c|c|c|c|}
\hline No. & Question & Not Agree & Neutral & Agree & Total \\
\hline 1. & Agricultural work stopped because of government measures during country lockdown & 8 & 3 & 89 & 100 \\
\hline 2. & Agricultural work stopped due to fear from COVID-19 infection & 24 & 0 & 76 & 100 \\
\hline 3. & Agricultural work stopped due to my infection with the Coronavirus & 0 & 1 & 99 & 100 \\
\hline 4. & The Corona pandemic has reduced wages or/and dismissal from work & 35 & 16 & 48 & 100 \\
\hline 5. & The lack of local agricultural labour during the Corona pandemic & 4 & 0 & 96 & 100 \\
\hline 6. & Lack of mobility license during the Corona pandemic & 91 & 2 & 7 & 100 \\
\hline 7. & $\begin{array}{l}\text { The closure of local and international fruit and vegetable markets as a result of the closure of the } \\
\text { borders led to damage of agricultural crops due to lack of harvest or crop accumulation }\end{array}$ & 13 & 3 & 84 & 100 \\
\hline 8. & The low prices of fruits and vegetables prevented their harvest and spoiled them during the pandemic & 4 & 35 & 61 & 100 \\
\hline 9. & $\begin{array}{l}\text { Agricultural policies and government measures facilitated the process of agricultural production and } \\
\text { the provision of food during the Corona pandemic }\end{array}$ & 19 & 9 & 72 & 100 \\
\hline 10. & $\begin{array}{l}\text { Agricultural policies and government measures have alleviated the effects of the Corona pandemic on } \\
\text { the agricultural sector }\end{array}$ & 19 & 9 & 72 & 100 \\
\hline & Mean & 21.7 & 7.8 & 70.4 & 100 \\
\hline
\end{tabular}

The study discusses the results of the targeted group's opinion in tow topics to show the real effect on the Jordanian agricultural sector as the following:

\subsection{The Impact of Agricultural Policies and Governmental Measures on Agricultural Marketing System During} the Corona Pandemic

According to the Table 7, COVID-19 governmental measures was affected the agricultural sector in Jordan, during the Corona pandemic and country lockdown, there was a significant differences with the lack of mobility license which causes lack of local agricultural Labour, although, labour salaries and reduction of employment by firing through dispensing of their services as a response of Corona pandemic governmental measures show a significant differences, also, Corona pandemic and government lockdown affected most of the economic sectors ; the closure of local and international fruit and vegetable markets and the closure of the borders led to damage of agricultural crops due to lack of harvest or crop accumulation which shows a significant difference according to the targeted group, delay crops harvest and/or unharvesting of agricultural crops due to low prices did not show significant differences, as a number of consumers explained through personal interviews, that the prices of vegetables and fruits did not decreased during the period of the Corona pandemic, while Mishra A. et al., 2021 indicated that, the negative income shock of COVID-19 restricted access to markets and increased prices of food commodities affecting the consumption pattern.

Table 7. The impact of agricultural policies and governmental measures on agricultural marketing system during the Corona pandemic

\begin{tabular}{|c|c|c|c|c|c|c|c|c|c|c|c|c|c|c|}
\hline \multirow{2}{*}{ Question } & \multicolumn{3}{|c|}{ Farmers } & \multicolumn{3}{|c|}{ Farm Labour } & \multicolumn{3}{|c|}{ Fruits \& veg. Traders } & \multicolumn{3}{|c|}{ Jordan Citizens } & \multirow{2}{*}{ Sig. } & \multirow{2}{*}{ LSD } \\
\hline & NA & $\mathrm{N}$ & A & NA & $\mathrm{N}$ & A & NA & $\mathrm{N}$ & A & NA & $\mathrm{N}$ & A & & \\
\hline $\begin{array}{l}\text { The Corona pandemic has reduced wages or/and dismissal } \\
\text { from work }\end{array}$ & 14 & 8 & 3 & 2 & 6 & 17 & 12 & 0 & 13 & 7 & 2 & 16 & $*$ & 0.425 \\
\hline The lack of local agricultural labour during the Corona pandemic & 0 & 0 & 25 & 0 & 0 & 25 & 3 & 0 & 22 & 1 & 0 & 24 & $*$ & 0.201 \\
\hline Lack of mobility license during the Corona pandemic & 25 & 0 & 0 & 25 & 0 & 0 & 23 & 0 & 2 & 18 & 2 & 5 & $*$ & 0.553 \\
\hline $\begin{array}{l}\text { The closure of local and international fruit and vegetable markets } \\
\text { and the closure of the borders led to damage of agricultural crops } \\
\text { due to lack of harvest or crop accumulation }\end{array}$ & 0 & 0 & 25 & 0 & 0 & 25 & 5 & 2 & 18 & 8 & 1 & 16 & * & 0.557 \\
\hline $\begin{array}{l}\text { The low prices of fruits and vegetables prevented their harvest } \\
\text { and spoiled them during the pandemic }\end{array}$ & 0 & 4 & 21 & 0 & 6 & 19 & 2 & 7 & 16 & 2 & 18 & 15 & ns & - \\
\hline
\end{tabular}

Note. NA: not agree; N: neutral; A: agree. ${ }^{*}$ Significant at $\mathrm{P} \leq 0.05$.

\subsection{The Impact of Agricultural Policies and Governmental Measures on Agricultural Production During the Corona Pandemic}

The results in a Table 8 indicated that the Agricultural production in Jordan was affected by government measures during the country lockdown, a significant difference appears with agricultural work which stopped working during the beginning of COVID-19 pandemic infection in Jordan, which was resulted from several conditions, 
some are due to fear of agricultural labour from COVID-19 infection, and/or due to actual infection with the Coronavirus, many articles expressed concern that farmers would stop producing because of the pandemic, as they get sick, (Cariappa A. et al., 2010), the same result was reported by Mishra A. et al. (2021) that, the pandemic has affected production and marketing through labour and logistical constraints. The restrictions on movement disrupted the supply chains, hampering the uninterrupted flow of inputs for and outputs of agricultural activities (Harris J. et al., 2020). Jordan government was aware of this situation, the Jordanian government tries to facilitate the process of agricultural production and the provision of food during the Corona pandemic, undoubtedly; the agricultural policies have alleviated the effects of the Corona pandemic on the agricultural sector which shows a significant difference.

Table 8. The impact of agricultural policies and government measures on agricultural production during the Corona pandemic

\begin{tabular}{|c|c|c|c|c|c|c|c|c|c|c|c|c|c|c|}
\hline \multirow{2}{*}{ Question } & \multicolumn{3}{|c|}{ Farmers } & \multicolumn{3}{|c|}{ Farm Labour } & \multicolumn{3}{|c|}{ Fruits \& veg. Traders } & \multicolumn{3}{|c|}{ Jordan Citizens } & \multirow{2}{*}{ Sig. } & \multirow{2}{*}{ LSD } \\
\hline & NA & $\mathrm{N}$ & A & NA & $\mathrm{N}$ & A & NA & $\mathrm{N}$ & A & NA & $\mathrm{N}$ & A & & \\
\hline $\begin{array}{l}\text { Agricultural work stopped because of governmental measures } \\
\text { during country lockdown }\end{array}$ & 0 & 1 & 24 & 0 & 2 & 23 & 6 & 0 & 19 & 2 & 0 & 23 & $*$ & 0.353 \\
\hline Agricultural work stopped due to fear from COVID-19 infection & 11 & 0 & 14 & 6 & 0 & 19 & 4 & 0 & 21 & 3 & 0 & 22 & $*$ & 0.212 \\
\hline Agricultural work stopped due to my infection with the Coronavirus & 0 & 0 & 25 & 0 & 1 & 24 & 0 & 0 & 25 & 0 & 0 & 25 & $*$ & 0.614 \\
\hline $\begin{array}{l}\text { Agricultural policies and government measures facilitated the } \\
\text { process of agricultural production and the provision of food } \\
\text { during the Corona pandemic }\end{array}$ & 12 & 5 & 8 & 2 & 0 & 23 & 5 & 3 & 17 & 0 & 1 & 24 & $*$ & 0.331 \\
\hline $\begin{array}{l}\text { Agricultural policies and government measures have alleviated } \\
\text { the effects of the Corona pandemic on the agricultural sector }\end{array}$ & 0 & 1 & 24 & 12 & 5 & 8 & 2 & 0 & 23 & 5 & 3 & 17 & $*$ & 0.259 \\
\hline
\end{tabular}

Note. NA: not agree; N: neutral; A: agree. * Significant at $\mathrm{P} \leq 0.05$.

\section{Conclusions}

Coronavirus crisis affected all economic sectors around the world, COVID-19 government response and measurements reflect on agricultural, COVID-19 was affected the Agricultural sector in Jordan at the beginning of the pandemic, the virus limits the free flow of labour, due to lack of mobility license, reduce agricultural labour salaries and reduction of agricultural employment by firing to reduce of production costs as a response of Corona pandemic governmental measures, also, agricultural work was stop due to fear of agricultural labour from COVID-19 infection, and/or actual infection with the Corona virus, data indicated that; the agricultural labour force did not highly decrease according to expectations; agricultural labour force was slight decreased at 2020 comparing with the year 2019 (7\% decreased), on the other hand, the closure of local and international fruit and vegetable markets and the closure of the borders led to damage of agricultural crops due to lack of harvest and/or crop accumulation, these effect was reflect on the Jordan Agricultural Contribution to GDP, the growth rate at current prices was decreased $1.4 \%$, the growth rate at constant prices was also decreased $1.6 \%$, according to all these effects; data shows that; the exported agricultural commodities value were not affected by COVID-19 pandemic but the imported of Agricultural commodities value was increased due to the high demand of Jordanian citizens to buy up huge stocks of durable food in relatively short time period causing difficulties for sale markets.

Jordan government was aware of this situation, the Jordanian government try to facilitate the process of agricultural production and the provision of food during the Corona pandemic, undoubtedly; the agricultural policies have excellent decisions to reduce the COVID-19 governmental measures on the agricultural sector, the study recommends that; there must be flexibility in agricultural policies to address any emergence factors affecting the Jordanian agricultural sector.

\section{References}

Bekkers, E. (2020). Trade and COVID-19: The WTO's 2020 and 2021 trade forecast. VoxEU \& CEPR. Retrieved April 28, 2020, from https://voxeu.org/article/trade-and-COVID-19-wto-s-2020-and-2021-trade-forecast

Cariappa, A., Acharya, K. K., Adhav, C. A., Sendhil, R., \& Ramasundaram, P. (2021). Impact of COVID-19 on the Indian agricultural system: A 10-point strategy for post-pandemic recovery. Outlook on Agriculture, 50(1), 26-33. https://doi.org/10.1177/0030727021989060 
FAO (Food and Agriculture Organization). (2020). Jordan Food Security Update May 2020. Retrieved from http://www.fao.org/3/cb1507en/CB1507EN.pdf

Google Health. (2020). COVID-19 Community Mobility Report Jordan. Retrieved from https://www.gstatic.com/ COVID19/mobility/2020-04-11_JO_Mobility_Report_en.pdf

Harris, J., Depenbusch, L., \& Pal, A. (2020). Food system disruption: Initial livelihood and dietary effects of COVID-19 on vegetable producers in India. Food Security, 12, 841-851. https://doi.org/10.1007/ s12571-020-01064-5

Jámbor, A., Czine, P., \& Balogh, P. (2020). The Impact of the Coronavirus on Agriculture: First Evidence Based on Global Newspapers. Sustainability, 12(11), 4535. https://doi.org/10.3390/su12114535

Jordan Department of Statistics. (2021). Retrieved from http://dosweb.dos.gov.jo

Jordan National Center for Security and Crises Management. (2020). COVID-19 in Jordan 2020. Retrieved April 16, 2020, from http://ncscm.gov.jo/index.php

Jordan Prime Minister Cabinate. (2020). Official reports. Retrieved April 17, 2020, from http://www.pm.gov.jo/ category/7603/?????.html

Jordan Prime Minister Cabinate. (2021). The latest decisions of the prime minister, 2021. Retrieved from https://portal.jordan.gov.jo/wps/portal/Home/Hukomati/PMNewsPaper

Jordanian Ministry of Health. (2020). COVID-19 in Jordan. Retrieved April 16, 2020, from https://corona.moh. gov.jo/ar

Kebede, T. A., Stave, S., Katta, M., \& Prokop, M. (2020). Impact of the COVID-19 pandemic on enterprises in Jordan. ILO, FAFO, UNDP. Retrieved from https://www.ilo.org/wcmsp5/groups/public/---arabstates/---robeirut/documents/publication/wcms_749136.pdf

Mishra, A., Bruno, E., \& Zilberman, D. (2021). Compound natural and human disasters: Managing drought and COVID-19 to sustain global agriculture and food sectors. Science of the Total Environment, 754, 142210. https://doi.org/10.1016/j.scitotenv.2020.142210

OECD (The Organisation for Economic Co-operation and Development). (2020). Evaluating the initial impact of COVID-19 containment measures on economic activity. Retrieved from https://read.oecdilibrary.org/ view/?ref=126_126496evgsi2gmqj\&title=Evaluating_the_initial_impact_of_COVID-19_containment_meas ures_on_economic_activity

Wikipedia. (2021). COVID-19 in Jordan, 2021. Retrieved from https://en.wikipedia.org/wiki/COVID-19_ pandemic_in_Jordan\#/media/File:COVID-19-Jordan-log.svg

Wikipedia. (2021). COVID-19 pandemic in Jordan. Retrieved from https://en.wikipedia.org/wiki/COVID-19_ pandemic_in_Jordan

WTO (World Trade Organization). (2020). Trade set to plunge as COVID-19 pandemic upends global economy. Retrieved from https://www.wto.org/english/news_e/pres20_e/pr855_e.htm

\section{Copyrights}

Copyright for this article is retained by the author(s), with first publication rights granted to the journal.

This is an open-access article distributed under the terms and conditions of the Creative Commons Attribution license (http://creativecommons.org/licenses/by/4.0/). 